Author affiliations and support information (if applicable) appear at the end of this article.

Published at jco.org on December 8, 2017

Corresponding author: Rick L. Haas, MD, $\mathrm{PhD}$, Department of Radiotherapy, The Netherlands Cancer Institute, Plesmanlaan 121, 1066 CX Amsterdam, NH 1066CX, the Netherlands; e-mail: r.haas@ nki.nl.

(c) 2017 by American Society of Clinical Oncology

$0732-183 X / 18 / 3602 w-118 w / \$ 20.00$

\title{
Perioperative Management of Extremity Soft Tissue Sarcomas
}

Rick L. Haas, Alessandro Gronchi, Michiel A.J. van de Sande, Elizabeth H. Baldini, Hans Gelderblom, Christina Messiou, Eva Wardelmann, and Axel Le Cesne

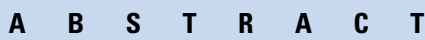

Surgery is potentially curative for primary nonmetastatic extremity soft tissue sarcomas. After surgery alone, patients may remain at risk for local recurrences and/or metastatic disease. To reduce the likelihood of a local relapse, the addition of radiotherapy (RT) to limb-sparing surgery may result in higher local control rates of at least $85 \%$. Generally, it can be stated that local control after both preoperative and postoperative RT is comparable, but that preoperative RT comes with a more favorable toxicity profile after prolonged follow-up, albeit at the cost of a higher wound complication rate. Furthermore, recent data suggest that preoperative RT is more cost effective. To reduce the risk of subsequent metastatic disease, systemic chemotherapy can be introduced early during the primary management of these patients. These systemic chemotherapy regimens can also be applied both preoperatively and postoperatively. Finally, with the aim of increasing the antitumor response of perioperative RT, these agents may even be combined with RT, concurrently and sequentially. While designing new preoperative combination regimens, responses should be carefully monitored by both sophisticated radiologic and pathologic evaluations. This article reviews all these aspects, in addition to limb-sparing surgery.

\section{J Clin Oncol 36:118-124. (C) 2017 by American Society of Clinical Oncology}

\section{INTRODUCTION}

The role of surgery aiming to cure primary nonmetastatic extremity soft tissue sarcomas (ESTS), is undebated. However, the addition of radiotherapy (RT) to limb-sparing surgery may result in higher local control rates of at least $85 \%$, especially when resection margins are negative, compared with surgery alone. ${ }^{1-4}$ This combined modality approach, as indicated by both National Comprehensive Cancer Network ${ }^{5}$ and European Society for Medical Oncology guidelines, ${ }^{6}$ has widely replaced the need for amputations. ${ }^{7}$

Predominantly dependent on age, histologic subtype, grade, and size, a substantial proportion of patients may develop subsequent metastatic disease. ${ }^{8}$ Attempts have been made to reduce this risk by the introduction of systemic chemotherapy early during the primary management of these patients. With the aim of increasing the antitumor response of perioperative RT, these agents may even be combined with RT, concurrently and sequentially. These aspects should be thoroughly discussed before management by experienced multidisciplinary teams in referral hospitals. Careful investigations on radiologic and pathologic response evaluation are mandatory, especially when new preoperative combination regimens are designed.

\section{Timing of Perioperative $R T$}

On the basis of the results of the Canadian SR-2 trial $^{1}$ and other nonrandomized comparisons, ${ }^{9,10}$ it can be stated that local control after both preoperative and postoperative RT is comparable. Recent data suggest that preoperative RT is more cost effective. ${ }^{11}$ The following sections discuss the main differences between both approaches.

\section{Postoperative $R T$}

Conventionally, the postoperative RT regimen consists of two phases. First, the entire operative bed (with a margin) is irradiated to 50 Gy in 1.8-2 Gy fractions followed by a boost of 10-16 Gy to the tumor site before surgery. Details on this regimen have been described previously. ${ }^{2}$ Because postoperative RT combines both large volumes and high doses, the long-term results include higher rates of permanent and progressive morbidities, such as fibrosis, joint stiffness, and edema $^{12}$ compared with patients treated with preoperative RT. Albeit, the incidence of early wound complications is lower. ${ }^{1}$ Studies from both Scandinavia ${ }^{13}$ and France ${ }^{14}$ have questioned the 
gain in local control by the 10-16 Gy boost after R0 resections. Currently, the question of timing is being investigated by the NCT02565498 study, which is a randomized trial comparing 50 Gy preoperative RT with 50 Gy postoperative RT after an R0 resection.

\section{Preoperative $R T$}

For preoperative RT, the volume of tissue irradiated is smaller, and the dose delivered is lower than during postoperative RT. Specifically, the tumor (plus a margin) is irradiated to 50 Gy in 1.8-2 Gy fractions. Although this regimen has been shown to result in an increased incidence of (sometimes severe) wound healing problems, ${ }^{1}$ these complications are of a temporary nature. Conversely, the permanent long-term complications of fibrosis, joint stiffness, and edema are reduced with preoperative RT compared with postoperative RT. ${ }^{12}$ Moreover, with the sarcoma in situ during preoperative RT, the opportunity arises to investigate individual and histotype-specific regimens with respect to fraction size, total dose, and combination with radiosensitizers.

In the past, several preoperative RT regimens with unconventional fraction sizes and/or total doses other than $50 \mathrm{~Gy}$ have been investigated, each with their own wound complication and local control profiles. Temple et $\mathrm{al}^{15}$ observed a relatively low wound complication rate of $15 \%$, while maintaining local control at $97 \%$ at 5 years of follow-up after $10 \times 3$ Gy. Between 1974 and 1987, Eilber et $\mathrm{al}^{16}$ performed three consecutive phase II studies, all applying 3.5 Gy fraction sizes. They eventually concluded the $8 \times 3.5$ Gy schedule provided the most favorable balance of local control and wound healing rates. ${ }^{16,17}$ In all these schedules, intra-arterial or intravenous doxorubicin was delivered during RT. The most extreme hypofractionation schedule to date is the Polish $5 \times 5$ Gy preoperative schedule, which enrolled 272 patients and reported a local control rate of $81 \%$ at 3 years. ${ }^{18}$

The histologic subtype myxoid liposarcoma is known for its exceptional radiation sensitivity, demonstrated by high local control rates after 50 Gy preoperatively. ${ }^{19}$ On the basis of this finding, an international prospective phase II clinical trial (NCT02106312) is investigating the efficacy of a reduced dose of $18 \times 2$ Gy for this subtype.

Experience with carcinomas has demonstrated that, compared with RT alone, concurrent regimens of preoperative (or definitive) RT in combination with systemic agents may result in improved local control and, sometimes, survival (albeit at the risk of an increased acute toxicity profile). Similar concurrent regimens have been explored for sarcomas aiming to increase antitumor efficacy and/or to use concurrent systemic agents as a means to lower the concurrent RT dose. Examples of tested combinations are ifosfamide $2,500 \mathrm{mg} / \mathrm{m}^{2}$ per day for 5 days $\left(+8 \times 3.5 \mathrm{~Gy}^{20}\right)$, epirubicin $30 \mathrm{mg} / \mathrm{m}^{2}$ per day, and ifosfamide $2,500 \mathrm{mg} / \mathrm{m}^{2}$ per day, both on days 1 to 4 $\left(+8 \times 3.5 \mathrm{~Gy}^{21}\right)$. Biologically more interesting are studies with targeted agents, such as bevacizumab in combination with $28 \times 1.8 \mathrm{~Gy},{ }^{22}$ sorafenib either in combination with $8 \times 3.5 \mathrm{~Gy}^{23}$ or with $25 \times 2 \mathrm{~Gy}{ }^{24}$ pazopanib with $25 \times 2 \mathrm{~Gy},{ }^{25}$ and sunitinib in combination with 50 to $50.4 \mathrm{~Gy} .{ }^{26,27}$ Except for concurrent single-agent ifosfamide, all these schedules seem to be associated with pathologic (near) complete response rates significantly higher than the $8 \%$ to $10 \%$ rates historically observed after RT alone, as listed in Table $1 .{ }^{28,29}$ However, it is important to point out that for soft tissue sarcoma (STS), pathologic response is not yet a valid surrogate end point. ${ }^{31}$ Of more clinical relevance are parameters such as local control and overall survival (OS), but they take years to mature. For now, outside the setting of well-designed prospective clinical trials, the 1.8-2 Gy fraction regimens should be considered the standard of care.

\section{Preoperative RT: Balancing Local Control and Surgical Complications}

The use of preoperative RT has offered new possibilities in limb salvage. After neoadjuvant therapy, narrow margins against critical structures can be allowed, while maintaining local control and functional outcome after resection ${ }^{3,32,33}$ because local control after both preoperative and postoperative RT seems comparable. ${ }^{1,9,10}$ An increased local control rate has been observed delivering preoperative RT when such an expected positive margin against critical structures is planned and expected. This has also been observed in

Table 1. Preoperative RT Series With Respect to Concurrent Systemic Therapy: Local Control and Histologic Response Rates Compared With RT Only

\begin{tabular}{|c|c|c|c|c|c|c|}
\hline Setting & First Author & No. & RT Regimen & $\begin{array}{l}\text { Chemotherapy } \\
\text { Regimen }\end{array}$ & $\begin{array}{c}\% \text { Local Control } \\
\text { at NN Years }\end{array}$ & (near) pCR, \% \\
\hline \multirow[t]{3}{*}{ RT only } & O'Sullivan ${ }^{1}$ & $94^{*}$ & $25 \times 2 \mathrm{~Gy}$ & - & 92 at $6.9+$ & - \\
\hline & Canter $^{28}$ & 25 & $25 \times 2 \mathrm{~Gy}$ & - & 100 at 3 & 8 \\
\hline & Shah $^{29}$ & 30 & $25 \times 2 \mathrm{~Gy}$ & - & 100 at 5 & 10 \\
\hline \multirow{3}{*}{$\begin{array}{l}\text { RT plus conventional } \\
\text { chemotherapy }\end{array}$} & MacDermed $^{20}$ & 34 & $8 \times 3.5 \mathrm{~Gy}$ & Ifosfamide & 89 at 5 & 11.8 \\
\hline & Ryan $^{21}$ & 25 & $8 \times 3.5 \mathrm{~Gy}$ & Epirubicin plus /ifosfamide & 88 at 2 & 40 \\
\hline & Gronchi $^{30}$ & 135 & $25 \times 2$ Gy & Epirubicin plus ifosfamide & 95.2 at 10 & - \\
\hline \multirow{6}{*}{$\begin{array}{l}\text { RT plus targeted } \\
\text { agents }\end{array}$} & Yoon $^{22}$ & 20 & $28 \times 1.8 \mathrm{~Gy}$ & Bevacizumab & 95 at 2 & 20 \\
\hline & Meyer $^{23}$ & 16 & $8 \times 3.5 \mathrm{~Gy}$ & Sorafenib & 100 at 2 & 44 \\
\hline & Canter $^{24}$ & 8 & $25 \times 2 \mathrm{~Gy}$ & Sorafenib & 100 at 3 & 38 \\
\hline & Haas $^{25}$ & 11 & $25 \times 2 \mathrm{~Gy}$ & Pazopanib & 91 at 2 & 40 \\
\hline & Jakob $^{26}$ & 9 & $28 \times 1.8 \mathrm{~Gy}$ & Sunitinib & 88 at 3 & 33 \\
\hline & Lewin $^{27}$ & 9 & $28 \times 1.8 \mathrm{~Gy}$ & Sunitinib & $\ddagger$ & $\S$ \\
\hline
\end{tabular}

Abbreviations: (near) pCR, defined as more than 95\% necrosis; NN, specified number of years follow-up; pCR, pathologic complete response; RT, radiotherapy. *Preoperative RT arm only.

tUpdate at ASCO and Connective Tissue Oncology Society presentations in 2004.

¥At 3.7 years median follow-up, five of nine had local relapses.

§Median percentage of necrosis was $75 \%$; range, $1 \%$ to $95 \%$, suggestive of a (near) pCR rate of $0 \%$. 
a recent trial combining preoperative chemotherapy and RT in highrisk STS after prolonged follow-up. ${ }^{30,34}$ Early wound healing difficulties are the disadvantage of this multimodality treatment strategy. ${ }^{1,35,36}$ Comparing results of prospective and retrospective studies, it must be noted that wound complications may occur in up to $42 \%$ of patients treated without (neo)adjuvant RT.,37-40 The Canadian SR-2 trial reported a significantly higher wound complication rate after neoadjuvant RT (17\% v 35\%), especially in the lower extremity $(20 \% v 43 \%){ }^{1}$ Comparable rates were observed in a study of patients $>70$ years old ( $40 \% v 19 \%)$, with a particular emphasis to the adductor compartment and the groin. ${ }^{41}$

In the modern era, the incidence of wound complications within a phase III study combining RT with anthracycline plus ifosfamide neoadjuvant chemotherapy in localized extremity or trunk wall STS was less than $20 \%$, whereas that of neoadjuvant chemotherapy followed by adjuvant external beam RT was $10 \% .^{42}$ Commonly, wound healing problems in low-risk patients are delayed and can be expected on average 3 weeks after surgery. ${ }^{35}$ When present, they are often successfully treated with modern wound healing strategies, such as vacuum treatment, and can therefore be regarded as temporary. Significant wound healing problems necessitating additional surgical intervention are uncommon. ${ }^{43,44}$

Although fully acknowledging the acute toxicity profile of preoperative RT as described above, two merits should be highlighted. First, long-term toxicity results are in support of neoadjuvant RT because less edema and fibrosis, fewer fractures, and superior limb function are reported. ${ }^{12,45}$ Second, preoperative RT may compensate for (anticipated) R1 resections. ${ }^{46-49}$ Furthermore, the acute toxicity profile inherent in preoperative RT can be mitigated by experienced surgeons in tertiary referral centers, using techniques such as free and pedicle flaps for high-risk locations (recurrences, large tumors, and lower extremity locations, especially in the adductor compartment and the groin). ${ }^{43,44,50,51}$

The patient's age and comorbidities should also influence decision making, because older age, obesity, vascular insufficiency, smoking, and diabetes have a negative effect on wound healing. Finally, some histologic subtypes are more sensitive than others (ie, myxoid liposarcoma, solitary fibrous tumor, extraskeletal myxoid chondrosarcoma, etc.), whereas some others have a higher local recurrence risk (ie, myxofibrosarcoma and malignant peripheral nerve sheath tumors)..$^{52,53}$

When a decision for RT is made, timing should be influenced by tumor characteristics, such as presentation (need to preserve function or not), site of origin, histologic subtype, and malignancy grade and size, as well as the patient's characteristics, as mentioned above. The balance of pros and cons might increasingly favor the use of preoperative RT, where its toxicities should be manageable in experienced centers.

\section{Timing of Perioperative Systemic Therapy: Adjuvant Chemotherapy}

For many bone tumors, perioperative chemotherapy is the standard of care. However, adjuvant chemotherapy has failed to prove an unequivocal clinical benefit in the heterogeneous group of STS. Nevertheless, the high rate of local or distant relapse and ultimate mortality (approximately 50\% for high-grade tumors), even after adequate local treatment of STS, ${ }^{54}$ has inevitably sustained the clinical interest of using adjuvant chemotherapy toward improving recurrence-free survival (RFS) and overall survival (OS).

An attempt to systematically analyze data on adjuvant chemotherapy, overcoming the problem of inadequately powered small trials and minimizing potential biases, was the 1997 Sarcoma Meta-Analysis Collaboration (SMAC). ${ }^{55}$ This landmark examination is the only STS meta-analysis to date on the basis of individual patient data. SMAC suggested adjuvant chemotherapy to significantly improve local and distant recurrence-free intervals $(4 \%$ at 10 years), especially for men and ESTS (7\% at 10 years; HR, 0.80; $P=.029)$. Pervaiz et $\mathrm{al}^{56}$ updated this meta-analysis in 2008 , adding another four trials, confirming the marginal efficacy of doxorubicinbased adjuvant chemotherapy.

After SMAC, the Italian Randomized Cooperative Trial, ${ }^{57}$ involving 104 high-grade patients with ESTS, studied an intensified adjuvant epirubicin/ifosfamide treatment arm (total cycle dose of ifosfamide, $9 \mathrm{~g} / \mathrm{m}^{2}$ ). After a median follow-up of 59 months, the study showed a significant improvement in median RFS and OS; however, it was not sustained at longer follow-up.

The most recent adjuvant chemotherapy trial, coordinated by the European Organization for Research and Treatment of CancerSoft Tissue and Bone Sarcoma Group (EORTC-STBSG), is the largest conducted to date. This study, involving 351 patients, failed to demonstrate any impact of adjuvant chemotherapy (five cycles of doxorubicin/ifosfamide) on either RFS or OS, especially after R0 resections. ${ }^{58,59}$

These trials should be included in new meta-analyses. Until then, adjuvant chemotherapy has not reproducibly improved RFS or OS in an unselected patient population, as listed in Table 2. Whether adjuvant chemotherapy can be proposed to high-risk individual patients in still-to-be-determined subtypes is a matter of shared decision making. ${ }^{6}$ New drugs, including novel molecularly driven agents, have been introduced in the treatment arena of STS. Future adjuvant chemotherapy trials with the same regimen for all STS subtypes are undeniably over. They should be driven by yet-to-be-identified and validated prognostic biomarkers. Options are (1) randomized trials in selected groups of histologic subtypes with specific systemic agents, (2) conventional chemotherapy in several STSs but with a specific molecular signature, ${ }^{61}$ and (3) selected regimens according to pathway signatures (eg, adjuvant imatinib in GI stromal tumors ${ }^{62}$ ).

\section{Induction (Neoadjuvant) Chemotherapy: Is It Better Than Adjuvant?}

For locally advanced STS, options to be discussed include neoadjuvant chemotherapy (NACT) with adequately dosed anthracyclines plus ifosfamide, ${ }^{63}$ isolated limb perfusion, or regional hyperthermia combined with chemotherapy. ${ }^{64,65}$

Several phase II trials have evaluated NACT combined with RT in series of up to 70 to 80 patients. ${ }^{66}$ However, lacking randomization, the exact benefit of these strategies in terms of progressionfree survival and the percentage of patients achieving limb-sparing resections has not been prospectively addressed. The only randomized trial comparing NACT followed by surgery with surgery only, reported by the EORTC-STBSG, failed to demonstrate a significant tumor control rate or survival advantage. ${ }^{67}$

Finally, a large prospective trial compared three cycles of a conventional, full-dosed, anthracycline-ifosfamide (EI) regimen 
Table 2. End Point Parameters in Adjuvant Chemotherapy Studies

\begin{tabular}{|c|c|c|c|c|c|}
\hline Parameter & SMAC55 & $\begin{array}{c}\text { Italian Cooperative } \\
\text { Study57 }\end{array}$ & EORTC-STBSG 6293158 & $\begin{array}{c}\text { Pooled Data EORTC- } \\
\text { STBSG } 62931 \text { and } \\
6277159\end{array}$ & $\begin{array}{l}\text { Italian, Spanish, French, } \\
\text { Polish Intergroup Study } \\
\text { (ISG-STS 1001)60 }\end{array}$ \\
\hline No. & 1,568 & $104 *$ & 351 & 819 & 287 \\
\hline Median follow-up & 9.4 years & $\begin{array}{l}59 \text { months (minimum } \\
\text { observation period } \\
36 \text { months) }\end{array}$ & 7.99 years & 8.2 years & 12.3 months \\
\hline Drugs & Doxorubicin based $t$ & $\begin{array}{l}\text { Per course: epirubicin } \\
120 \mathrm{mg} / \mathrm{m}^{2}+ \\
\text { ifosfamide } 9 \mathrm{~g} / \mathrm{m}^{2} \text {; total } \\
5 \text { courses }\end{array}$ & $\begin{array}{l}\text { Per course: doxorubicin } \\
75 \mathrm{mg} / \mathrm{m}^{2}+\text { ifosfamide } \\
5 \mathrm{~g} / \mathrm{m}^{2} \text {; total } 5 \text { courses. }\end{array}$ & $\begin{array}{l}\text { For } 62931 \text { : doxorubicin } \\
75 \mathrm{mg} / \mathrm{m}^{2}+\text { ifosfamide } \\
5 \mathrm{~g} / \mathrm{m}^{2} \text {, total } 5 \\
\text { courses } 58 \text { For } 62771 \text { : } \\
\text { CYVADIC }\end{array}$ & $\begin{array}{l}\text { Histo-type based } v \\
\text { standard epirubicin } \\
120 \mathrm{mg} / \mathrm{m}^{2}+ \\
\text { ifosfamide } 9 \mathrm{~g} / \mathrm{m}^{2}\end{array}$ \\
\hline Local RFI & $\begin{array}{l}\mathrm{HR}, 0.73 \text { (0.56 to } 0.94) \\
\quad P=.016\end{array}$ & - & - & - & $85 \% v 86 \%$ at 46 months \\
\hline $\begin{array}{l}\text { Absolute local relapse- } \\
\text { free benefit at NN } \\
\text { years }(\mathrm{Cl})\end{array}$ & $\begin{array}{l}6 \% \text { at } 10 \text { years }(1 \% \text { to } \\
10 \%)\end{array}$ & $\begin{array}{c}0 \% \vee 10 \% \text { at } 2 \text { years } \\
(P=.02), 6 \% \vee 17 \% \\
\text { at } 4 \text { years }(P=.09)\end{array}$ & $18.9 \%$ v $23.7 \%$ at 5 years & - & \\
\hline Distant RFI & $\begin{array}{l}\mathrm{HR}, 0.70(0.57 \text { to } 0.85) \\
\quad P=.0003\end{array}$ & - & - & - & $\begin{array}{c}\mathrm{HR}, 2.147(1.172 \text { to } \\
3.930) ; P=.011\end{array}$ \\
\hline $\begin{array}{l}\text { Absolute distant } \\
\text { relapse-free benefit } \\
\text { at } \mathrm{NN} \text { years }(\mathrm{Cl})\end{array}$ & $\begin{array}{l}10 \% \text { at } 10 \text { years }(5 \% \text { to } \\
15 \%)\end{array}$ & $\begin{array}{c}28 \% \vee 45 \% \text { at } 2 \text { years } \\
(P=.08), 44 \% \vee 45 \% \text { at } \\
4 \text { years }(P=0.94)\end{array}$ & - & - & $45 \% \vee 74 \%$ at 46 months \\
\hline Overall RFI & $\begin{array}{l}\mathrm{HR}, 0.75 \text { (0.64 to 0.87); } \\
\quad P<.001\end{array}$ & $\begin{array}{l}\mathrm{HR}, 0.59 \text { (0.36 to } 0.99) \\
\quad P=.04\end{array}$ & $\begin{array}{l}\mathrm{HR}, 0.91(0.67 \text { to } 1.22) \\
\quad P=.51\end{array}$ & - & - \\
\hline $\begin{array}{l}\text { Absolute overall } \\
\text { relapse-free benefit } \\
\text { at } N N \text { years }(\mathrm{Cl})\end{array}$ & $\begin{array}{c}10 \% \text { at } 10 \text { years }(5 \% \text { to } \\
15 \%)\end{array}$ & $\begin{array}{l}27 \% \text { at } 2 \text { years, } 13 \% \text { at } \\
4 \text { years }\end{array}$ & & - & - \\
\hline Overall survival & $\begin{array}{l}\mathrm{HR}, 0.89 \text { (0.76 to } 1.03) \\
\quad P=.12\end{array}$ & $\begin{array}{l}\mathrm{HR}, 0.52 \text { (0.29 to } 0.93) \\
P=.03\end{array}$ & $\begin{array}{l}\mathrm{HR}, 0.94(0.68 \text { to } 1.31) \\
P=.72\end{array}$ & - & $\begin{array}{c}\mathrm{HR}, 2.687(1.104 \text { to } \\
6.940) ; P=.034\end{array}$ \\
\hline $\begin{array}{l}\text { Absolute overall } \\
\text { survival benefit at } \\
\text { NN years }(\mathrm{Cl})\end{array}$ & $4 \%$ at 10 years ( $1 \%$ to $9 \%$ ) & $\begin{array}{c}13 \% \text { at } 2 \text { years, } 19 \% \text { at } \\
4 \text { years; } P=.04\end{array}$ & & $\begin{array}{l}\text { After marginal resection: } \\
27.6 \% \text { V } 44.7 \% \text { at } \\
10 \text { years, } P=.048 ; \text { after } \\
\text { optimal resection: } \\
\text { approximately } 60 \% \\
\text { with or without } \\
\text { chemotherapy } \\
\text { regardless of sex or age }\end{array}$ & $64 \% v 89 \%$ at 46 months \\
\hline Subgroup analyses & $\begin{array}{l}\text { Men benefit more than } \\
\text { women; extremities } \\
\text { benefit more than other } \\
\text { locations }\end{array}$ & $\begin{array}{l}\text { No significant differences } \\
\text { for age, sex, center of } \\
\text { surgery, histology, } \\
\text { grading, site of primary } \\
\text { tumor, presentation, } \\
\text { diameter, local } \\
\text { treatment, and } \\
\text { stratification }\end{array}$ & $\begin{array}{l}\text { Trends toward more } \\
\text { benefit from } \\
\text { chemotherapy for } \\
\text { larger, high-grade, and } \\
\text { extremity tumors were } \\
\text { not significant }\end{array}$ & $\begin{array}{l}\text { Men benefit more than } \\
\text { women; chemotherapy } \\
\text { detrimental in younger } \\
\text { women?; patients age } \\
>40 \text { years benefit more } \\
\text { than younger patients; } \\
\text { marginal } v \text { radical } \\
\text { resection negatively } \\
\text { influenced overall } \\
\text { survival; adjuvant } \\
\text { CYVADIC reduced local } \\
\text { recurrence rate without } \\
\text { any impact on survival }\end{array}$ & $\begin{array}{l}\text { Difference in disease-free } \\
\text { survival favoring } \\
\text { standard chemotherapy } \\
\text { was consistently seen } \\
\text { in all strata except for } \\
\text { high-grade myxoid } \\
\text { liposarcoma }\end{array}$ \\
\hline DI & & $\begin{array}{l}\text { Average median relative } \\
\text { DI: } 83.3 \%, 63 \% \text { of } \\
\text { cycles at DI } \geq 80 \%, \\
48 \% \text { of cycles at } \mathrm{DI} \geq \\
90 \%\end{array}$ & $\begin{array}{l}80 \% \text { completed full } 5 \\
\text { cycles, } 68 \% \text { received } \\
\text { full dose on time; } 22 \% \\
\text { delays, } 6 \% \text { dose } \\
\text { reductions, and } 4 \% \\
\text { both }\end{array}$ & & $\begin{array}{l}10 \% \vee 18 \% \text { dose } \\
\text { reductions }\end{array}$ \\
\hline
\end{tabular}

Abbreviations: CYVADIC, doxorubicin $50 \mathrm{mg} / \mathrm{m}^{2}$ day 1 , dacarbazine $400 \mathrm{mg} / \mathrm{m}^{2}$ days $1-3$, cyclophosphamide $500 \mathrm{mg} / \mathrm{m}^{2}$ day 1 , and vincristine $1.5 \mathrm{mg} / \mathrm{m}^{2}$ day 1 ; DI, dose intensity; EORTC-STBSG, European Organization for Research and Treatment of Cancer Soft Tissue and Bone Sarcoma Group; HR, hazard ratio; NN, specified number of years follow-up; RFI, recurrence-free interval; SMAC, Sarcoma Meta-analysis Collaboration.

*Preplanned interim analysis revealed benefit for chemotherapy, $P=.001$.

tDoxorubicin dose per study predominantly $50-70 \mathrm{mg} / \mathrm{m}^{2}$ and cumulative $400-550 \mathrm{mg}$.

with histotype-tailored chemotherapy (HT-CT) in localized, highgrade, $>5-\mathrm{cm}$, adult ESTS, ${ }^{60}$ aiming to reduce the relapse risk with the HT-CT regimen by $30 \%$. The HT-CT regimen in the experimental arm was based on results observed in the advanced setting during the last decade. ${ }^{42}$ After a median follow-up of more than 1 year, unexpectedly, patients receiving EI experienced a better prognosis. The projected RFS at 4 years was $62 \%$ with the EI regimen versus $38 \%$ in the experimental arm. After 70 events, at the third preplanned interim analysis, the study was closed. The results observed in the experimental arm are surprising. Whatever the hypotheses, EI compared with HT-CT is still superior in most common subtypes of localized STS.

Referral to specialized centers of all patients with (suspected) STS will help to develop precision medicine programs to identify new actionable targets and new ambitious programs, even in the context of localized diseases. ${ }^{68-71}$ The collection of fresh/frozen tissue and tumor imprints is encouraged because new molecular pathology assessments could be made at a later stage in the patient's interest. 


\section{Pathologic Response Evaluation After Preoperative Therapy}

Whereas several clinical trials have demonstrated the relevance of histopathologic appearance in bone sarcomas, mainly in osteosarcomas and Ewing sarcomas, it is still under debate whether there should be a comparable response evaluation scheme for STS. Generally accepted rules on how the tumor specimen should be worked up after preoperative treatment and how the results should be reported are lacking. However, the EORTC-STBSG has proposed a standardized protocol for neoadjuvant therapy response assessment on the basis of a consensus of their STS experienced reference pathologists. They proposed a five-tier histologic response score on the basis of the percentage of remaining stainable tumor cells ranging from zero to $>50 \% .{ }^{72}$ Subsequently, this proposed response score was assessed for its prognostic value by another group at Harvard Medical School in Boston. ${ }^{31}$ In this retrospective study of 100 patients with STS treated with preoperative RT, The EORTC-STBSG response score was not found to be prognostic, but the extent of hyalinization and fibrosis was associated with a favorable outcome. These results can only be viewed as hypothesis generating, and a prospective trial with well-defined criteria for specimen analysis is necessary.

Furthermore, after neoadjuvant treatment, it is difficult if not impossible to evaluate whether areas of necrosis are the result of the treatment or have been a consequence of insufficient blood supply due to insufficient neovascularization. Therefore, it seems to be more effective to estimate the percentage of remaining tumor cells, although their tumorigenic capability cannot be seen under the microscope. In summary, a prospective clinical trial including high-grade sarcomas in defined locations that are evaluated by a consensus protocol developed by a group of pathologists will be the only way to clarify the relevance of preoperative neoadjuvant treatment.

\section{Radiologic Response Evaluation After Preoperative Therapy}

Magnetic resonance imaging (MRI) is standard imaging before and after RT. However, histopathologic changes that occur after RT confound dimension-based assessments of response. Except for myxoid liposarcoma, ${ }^{73}$ significant dimensional radiologic responses after preoperative RT are rare events and have been reported to be as low as $0 \% .^{28}$ Consequently, dimension-based assessments have been shown to have no correlation with outcome or histopathologic response, ${ }^{74,75}$ and alternative response assessments are needed. Tumor characteristics on computed tomography scans (such as the Choi criteria) or tumor contrast enhancement at MRI may complement tumor size as a criterion to better predict pathologic response. In a study of neoadjuvant chemotherapy or chemoradiotherapy response to chemotherapy with or without RT was associated with a better outcome in patients with high-risk STS, and Choi criteria were better predictors than conventional Response Evaluation Criteria In Solid Tumors. ${ }^{76,77}$ Although in standard clinical practice, post-RT imaging of the primary sarcoma is unlikely to alter the decision regarding operability, ${ }^{78}$ evolving therapeutic options do require a robust assessment of response and clinical trials necessitate quantitative measurements.

Current consensus from the EORTC-STBSG suggests that the addition of functional diffusion-weighted MRI (DW-MRI) to standard anatomic and postcontrast MRI greatly facilitates interpretation because the combination of reduced enhancement and increasing apparent diffusion coefficient (ADC) may increase confidence for response. ${ }^{79}$ After RT, new enhancement alone should be interpreted with caution because this may be a result of vascular disruption rather than histologic response. Moving forward into clinical trials, DW-MRI is also promising as a quick, noninvasive tool showing excellent reproducibility for ADC measurements, which reflect tumor cellularity and microarchitecture in STS (coefficient of variation $[\mathrm{CoV}], 1.7 \%) .{ }^{80}$ Preclinical data suggest that DW-MRI may also be valuable in assessments as early as 2 days after RT. ${ }^{81}$ ADC can be supplemented with quantitative measures of perfusion, such as enhancing fraction (CoV, 8.6\%), or modelbased measures, such as $\mathrm{K}^{\text {trans }}(\mathrm{CoV}, 13.9 \%){ }^{82}$ Dual baseline quantitative MRI allows individual patient response assessments rather than cohort measures, which may not reflect response in heterogeneous patient groups. However, the relationship of these MRI parameter changes with clinical outcomes has not yet been validated; therefore, their use as clinical trial end points must be carefully considered and used in conjunction with proven end points (such as local control and survival). Alternative methods of assessment are also poorly understood; however, a small study of $\left[{ }^{18} \mathrm{~F}\right]$ fluorodeoxyglucose positron-emission tomography/computed tomography in high-grade sarcomas did show some promise for fluorodeoxyglucose uptake measurements of standardized uptake value. $^{83}$

In conclusion, nonmetastatic sarcomas should be surgically removed whenever possible. Perioperatively, the addition of RT and/or chemotherapy should be considered, on the basis of both tumor and patient characteristics. With respect to radiation, applying RT preoperatively should be considered. These discussions should take place between patients and experienced teams in tertiary referral centers. Treatment-related early end points, such as radiologic and histologic response, are appealing and should be included in future prospective trials to assess for correlations with clinical outcomes, such as local control and survival.

\section{AUTHORS' DISCLOSURES OF POTENTIAL CONFLICTS} OF INTEREST

Disclosures provided by the authors are available with this article at jco.org.

\section{AUTHOR CONTRIBUTIONS}

Conception and design: Rick L. Haas, Alessandro Gronchi, Elizabeth H. Baldini, Hans Gelderblom, Christina Messiou, Eva Wardelmann, Axel Le Cesne

Collection and assembly of data: Rick L. Haas, Alessandro Gronchi, Elizabeth H. Baldini, Hans Gelderblom, Christina Messiou, Eva Wardelmann

Data analysis and interpretation: Rick L. Haas, Alessandro Gronchi, Michiel A.J. van de Sande, Elizabeth H. Baldini, Hans Gelderblom, Christina Messiou, Eva Wardelmann

Manuscript writing: All authors

Final approval of manuscript: All authors

Accountable for all aspects of the work: All authors 


\section{REFERENCES}

1. O'Sullivan B, Davis AM, Turcotte $R$, et al: Preoperative versus postoperative radiotherapy in soft-tissue sarcoma of the limbs: A randomised trial. Lancet 359:2235-2241, 2002

2. Haas RL, Delaney TF, O'Sullivan B, et al: Radiotherapy for management of extremity soft tissue sarcomas: Why, when, and where? Int J Radiat Oncol Biol Phys 84:572-580, 2012

3. Beane JD, Yang JC, White D, et al: Efficacy of adjuvant radiation therapy in the treatment of soft tissue sarcoma of the extremity: 20-year follow-up of a randomized prospective trial. Ann Surg Oncol 21: 2484-2489, 2014

4. Pisters PW, Harrison LB, Leung DH, et al: Long-term results of a prospective randomized trial of adjuvant brachytherapy in soft tissue sarcoma. J Clin Oncol 14:859-868, 1996

5. von Mehren M, Randall RL, Benjamin RS, et al: Soft tissue sarcoma, version 2.2014. J Natl Compr Canc Netw 12:473-483, 2014

6. ESMO/European Sarcoma Network Working Group: Soft tissue and visceral sarcomas: ESMO Clinical Practice guidelines for diagnosis, treatment and followup. Ann Oncol 25:iii102-iii112, 2014 (suppl 3)

7. Rosenberg SA, Tepper J, Glatstein E, et al: The treatment of soft-tissue sarcomas of the extremities: Prospective randomized evaluations of (1) limb-sparing surgery plus radiation therapy compared with amputation and (2) the role of adjuvant chemotherapy. Ann Surg 196:305-315, 1982

8. Callegaro $D$, Miceli $R$, Bonvalot $S$, et al: Development and external validation of two nomograms to predict overall survival and occurrence of distant metastases in adults after surgical resection of localised soft-tissue sarcomas of the extremities: A retrospective analysis. Lancet Oncol 17:671-680, 2016

9. Willeumier JJ, Rueten-Budde AJ, Jeys LM, et al: Individualised risk assessment for local recurrence and distant metastases in a retrospective transatlantic cohort of 687 patients with high-grade soft tissue sarcomas of the extremities: A multistate model. BMJ Open 7:e012930, 2017

10. Müller DA, Beltrami G, Scoccianti G, et al: Combining limb-sparing surgery with radiation therapy in high-grade soft tissue sarcoma of extremitiesIs it effective? Eur J Surg Oncol 42:1057-1063, 2016

11. Qu XM, Louie AV, Ashman J, et al: Costeffectiveness analysis of preoperative versus postoperative radiation therapy in extremity soft tissue sarcoma. Int J Radiat Oncol Biol Phys 97:339-346, 2017

12. Davis AM, O'Sullivan B, Turcotte $R$, et al: Late radiation morbidity following randomization to preoperative versus postoperative radiotherapy in extremity soft tissue sarcoma. Radiother Oncol 75:48-53, 2005

13. Jebsen NL, Trovik CS, Bauer HC, et al: Radiotherapy to improve local control regardless of surgical margin and malignancy grade in extremity and trunk wall soft tissue sarcoma: A Scandinavian sarcoma group study. Int J Radiat Oncol Biol Phys 71: 1196-1203, 2008

14. Milbéo $Y$, Kantor $G$, Laharie $H$, et al: Adjuvant radiation therapy for soft tissue sarcoma of the extremities: Analysis of local control according to volume and dose [in French]. Cancer Radiother 9:293303, 2005

15. Temple WJ, Temple $C L$, Arthur $K$, et al: Prospective cohort study of neoadjuvant treatment in conservative surgery of soft tissue sarcomas. Ann Surg Oncol 4:586-590, 1997

16. Eilber F, Eckardt J, Rosen G, et al: Preoperative therapy for soft tissue sarcoma. Hematol Oncol Clin North Am 9:817-823, 1995

17. Ryan JR, Baker LO (eds): Neoadjuvant chemotherapy, radiation, and limited surgery for high grade soft tissue sarcoma of the extremity, in: Recent Concepts in Sarcoma Treatment. Dordrecht, the Netherlands, Kluwer Academic Publishers, 1988, pp. 115-122

18. Koseła-Paterczyk H, Szacht M, Morysiński T, et al: Preoperative hypofractionated radiotherapy in the treatment of localized soft tissue sarcomas. Eur J Surg Oncol 40:1641-1647, 2014

19. Chung PW, Deheshi BM, Ferguson PC, et al: Radiosensitivity translates into excellent local control in extremity myxoid liposarcoma: A comparison with other soft tissue sarcomas. Cancer 115:3254-3261, 2009

20. MacDermed DM, Miller LL, Peabody TD, et al: Primary tumor necrosis predicts distant control in locally advanced soft-tissue sarcomas after preoperative concurrent chemoradiotherapy. Int J Radiat Oncol Biol Phys 76:1147-1153, 2010

21. Ryan CW, Montag AG, Hosenpud JR, et al: Histologic response of dose-intense chemotherapy with preoperative hypofractionated radiotherapy for patients with high-risk soft tissue sarcomas. Cancer 112:2432-2439, 2008

22. Yoon SS, Duda DG, Karl DL, et al: Phase ॥ study of neoadjuvant bevacizumab and radiotherapy for resectable soft tissue sarcomas. Int J Radiat Oncol Biol Phys 81:1081-1090, 2011

23. Meyer JM, Perlewitz KS, Hayden JB, et al: Phase I trial of preoperative chemoradiation plus sorafenib for high-risk extremity soft tissue sarcomas with dynamic contrast-enhanced MRI correlates. Clin Cancer Res 19:6902-6911, 2013

24. Canter RJ, Borys D, Olusanya A, et al: Phase I trial of neoadjuvant conformal radiotherapy plus sorafenib for patients with locally advanced soft tissue sarcoma of the extremity. Ann Surg Oncol 21: 1616-1623, 2014

25. Haas RL, Gelderblom H, Sleijfer $S$, et al: A phase I study on the combination of neoadjuvant radiotherapy plus pazopanib in patients with locally advanced soft tissue sarcoma of the extremities. Acta Oncol 54:1195-1201, 2015

26. Jakob J, Simeonova A, Kasper B, et al: Combined radiation therapy and sunitinib for preoperative treatment of soft tissue sarcoma. Ann Surg Oncol 22:2839-2845, 2015

27. Lewin J, Khamly KK, Young RJ, et al: A phase Ib/ll translational study of sunitinib with neoadjuvant radiotherapy in soft-tissue sarcoma. $\mathrm{Br} \mathrm{J}$ Cancer 111: 2254-2261, 2014

28. Canter RJ, Martinez SR, Tamurian RM, et al: Radiographic and histologic response to neoadjuvant radiotherapy in patients with soft tissue sarcoma. Ann Surg Oncol 17:2578-2584, 2010

29. Shah D, Borys D, Martinez SR, et al: Complete pathologic response to neoadjuvant radiotherapy is predictive of oncological outcome in patients with soft tissue sarcoma. Anticancer Res 32:3911-3915, 2012

30. Gronchi A, Verderio P, De Paoli A, et al: Quality of surgery and neoadjuvant combined therapy in the ISG-GEIS trial on soft tissue sarcomas of limbs and trunk wall. Ann Oncol 24:817-823, 2013

31. Schaefer I-M, Hornick JL, Barysauskas CM, et al: Histologic appearance following pre-operative radiation therapy for soft tissue sarcoma: Assessment of the
EORTC-STBSG Response Score. Int J Radiat Oncol Biol Phys 98:375-383, 2017

32. Yang JC, Chang $A E$, Baker $A R$, et al: Randomized prospective study of the benefit of adjuvant radiation therapy in the treatment of soft tissue sarcomas of the extremity. J Clin Oncol 16:197-203, 1998

33. Singer $S$, Demetri $G D$, Baldini $E H$, et al: Management of soft-tissue sarcomas: An overview and update. Lancet Oncol 1:75-85, 2000

34. Gronchi A, Stacchiotti $S$, Verderio $P$, et al: Short, full-dose adjuvant chemotherapy (CT) in highrisk adult soft tissue sarcomas (STS): Long-term follow-up of a randomized clinical trial from the Italian Sarcoma Group and the Spanish Sarcoma Group. Ann Oncol 27:2283-2288, 2016

35. Griffin AM, Dickie $\mathrm{Cl}$, Catton $\mathrm{CN}$, et al: The influence of time interval between preoperative radiation and surgical resection on the development of wound healing complications in extremity soft tissue sarcoma. Ann Surg Oncol 22:2824-2830, 2015

36. Cannon CP, Ballo MT, Zagars GK, et al: Complications of combined modality treatment of primary lower extremity soft-tissue sarcomas. Cancer 107:2455-2461, 2006

37. Miller ED, Xu-Welliver M, Haglund KE: The role of modern radiation therapy in the management of extremity sarcomas. J Surg Oncol 111:599-603, 2015

38. Kuklo TR, Temple HT, Owens BD, et al: Preoperative versus postoperative radiation therapy for soft-tissue sarcomas. Am J Orthop 34:75-80, 2005

39. Grainger MF, Grimer RJ, Carter SR, et al: Wound complications following resection of adductor compartment tumours. Sarcoma 5:203-207, 2001

40. Baldini EH, Lapidus MR, Wang Q, et al: Predictors for major wound complications following preoperative radiotherapy and surgery for soft-tissue sarcoma of the extremities and trunk: Importance of tumor proximity to skin surface. Ann Surg Oncol 20: 1494-1499, 2013

41. Andrä $C$, Klein $A$, Dürr HR, et al: External-beam radiation therapy combined with limb-sparing surgery in elderly patients ( $>70$ years) with primary soft tissue sarcomas of the extremities: A retrospective analysis. Strahlenther Onkol 193:604-611, 2017

42. Palassini E, Ferrari $S$, Verderio $P$, et al: Feasibility of preoperative chemotherapy with or without radiation therapy in localized soft-tissue sarcomas of limbs and superficial trunk in the Italian Sarcoma Group/Grupo Español de Investigacion en Sarcomas Randomized Clinical Trial: Three versus five cycles of full-dose epirubicin plus ifosfamide. J Clin Oncol 33: 3628-3634, 2015

43. Temple CL, Ross DC, Magi E, et al: Preoperative chemoradiation and flap reconstruction provide high local control and low wound complication rates for patients undergoing limb salvage surgery for upper extremity tumors. J Surg Oncol 95: 135-141, 2007

44. Lohman RF, Nabawi AS, Reece GP, et al: Soft tissue sarcoma of the upper extremity: A 5-year experience at two institutions emphasizing the role of soft tissue flap reconstruction. Cancer 94:2256-2264, 2002

45. Dickie $\mathrm{Cl}$, Parent $\mathrm{AL}$, Griffin $\mathrm{AM}$, et al: Bone fractures following external beam radiotherapy and limb-preservation surgery for lower extremity soft tissue sarcoma: Relationship to irradiated bone length, volume, tumor location and dose. Int J Radiat Oncol Biol Phys 75:1119-1124, 2009

46. Dagan R, Indelicato DJ, McGee L, et al: The significance of a marginal excision after preoperative 
radiation therapy for soft tissue sarcoma of the extremity. Cancer 118:3199-3207, 2012

47. Al Yami A, Griffin AM, Ferguson PC, et al: Positive surgical margins in soft tissue sarcoma treated with preoperative radiation: Is a postoperative boost necessary? Int J Radiat Oncol Biol Phys 77: 1191-1197, 2010 The effect of the setting of a positive surgical margin in soft tissue sarcoma. Cancer 120:2866-2875, 2014 post-operative radiation boost for soft tissue sarcomas with positive margins following pre-operative radiation and surgery. J Surg Oncol 110:817-822, 2014

50. Chao AH, Chang DW, Shuaib SW, et al: The effect of neoadjuvant versus adjuvant irradiation on microvascular free flap reconstruction in sarcoma patients. Plast Reconstr Surg 129:675-682, 2012

51. López JF, Hietanen KE, Kaartinen IS, et al: Primary flap reconstruction of tissue defects after sarcoma surgery enables curative treatment with acceptable functional results: A 7-year review. BMC Surg 15:71, 2015

52. Haas RLM, Miah AB, LePechoux $C$, et al: Preoperative radiotherapy for extremity soft tissue sarcoma; past, present and future perspectives on dose fractionation regimens and combined modality strategies. Radiother Oncol 119:14-21, 2016

53. Gronchi A, Colombo C, Raut CP: Surgical management of localized soft tissue tumors. Cancer 120:2638-2648, 2014

54. Devita VT, Lawrence TS, Rosenberg SA (eds): Sarcomas of the soft tissue and bone (ed 8), in: Cancer Principles and Practice of Oncology. Philadelphia, PA, Lippincott Williams and Wilkins, 2008, pp 1741-1794

55. Sarcoma Meta-Analysis Collaboration: Adjuvant chemotherapy for localised resectable soft-tissue sarcoma of adults: Meta-analysis of individual data. Lancet 350:1647-1654, 1997

56. Pervaiz N, Colterjohn N, Farrokhyar F, et al: A systematic meta-analysis of randomized controlled trials of adjuvant chemotherapy for localized resectable soft-tissue sarcoma. Cancer 113:573-581, 2008

57. Frustaci S, Gherlinzoni F, De Paoli A, et al: Adjuvant chemotherapy for adult soft tissue sarcomas of the extremities and girdles: Results of the Italian randomized cooperative trial. J Clin Oncol 19: 1238-1247, 2001

58. Woll PJ, Reichardt $P$, Le Cesne $A$, et al: Adjuvant chemotherapy (CT) with doxorubicin and ifosfamide in resected soft tissue sarcoma (STS): Interim analysis of a randomized phase III trial. Lancet Oncol 13:1045-1054, 2012

59. Le Cesne A, Ouali M, Leahy MG, et al: Doxorubicinbased adjuvant chemotherapy in soft tissue sarcoma:
48. O'Donnell PW, Griffin AM, Eward WC, et al:

49. Pan E, Goldberg SI, Chen YL, et al: Role of
Pooled analysis of two STBSG-EORTC phase III clinical trials. Ann Oncol 25:2425-2432, 2014

60. Gronchi A, Ferrari S, Quagliuolo V, et al: Histotype-tailored neoadjuvant chemotherapy versus standard chemotherapy in patients with high-risk softtissue sarcomas (ISG-STS 1001): An international, openlabel, randomised, controlled, phase 3, multicentre trial. Lancet Oncol 18:812-822, 2017

61. Chibon F, Lagarde $P$, Salas $S$, et al: Validated prediction of clinical outcome in sarcomas and multiple types of cancer on the basis of a gene expression signature related to genome complexity. Nat Med 16 781-787, 2010

62. Dematteo RP, Ballman KV, Antonescu CR, et al: Adjuvant imatinib mesylate after resection of localised, primary gastrointestinal stromal tumour: A randomised, double-blind, placebo-controlled trial. Lancet 373:1097-1104, 2009

63. Bramwell VH, Anderson $\mathrm{D}$, Charette $\mathrm{ML}$ : Doxorubicin-based chemotherapy for the palliative treatment of adult patients with locally advanced or metastatic soft-tissue sarcoma: A meta-analysis and clinical practice guideline. Sarcoma 4:103-112, 2000

64. Issels RD, Lindner LH, Verweij J, et al: Neoadjuvant chemotherapy alone or with regional hyperthermia for localised high-risk soft-tissue sarcoma: A randomised phase 3 multicentre study. Lancet Oncol 11:561-570, 2010

65. Deroose JP, Eggermont AM, van Geel AN, et al: Long-term results of tumor necrosis factor alphaand melphalan-based isolated limb perfusion in locally advanced extremity soft tissue sarcomas. J Clin Oncol 29:4036-4044, 2011

66. Schuetze SM, Patel S: Should patients with high-risk soft tissue sarcoma receive adjuvant chemotherapy? Oncologist 14:1003-1012, 2009

67. Gortzak E, Azzarelli A, Buesa J, et al: A randomised phase II study on neo-adjuvant chemotherapy for 'high-risk' adult soft-tissue sarcoma. Eur $J$ Cancer 37:1096-1103, 2001

68. Davoli $T, X u A W$, Mengwasser KE, et al: $\mathrm{Cu}$ mulative haploinsufficiency and triplosensitivity drive aneuploidy patterns and shape the cancer genome. Cell 155:948-962, 2013

69. Jiang $X$, Pissaloux $D$, De La Fouchardiere $C$, et al: The sum of gains and losses of genes encoding the protein tyrosine kinase targets predicts response to multi-kinase inhibitor treatment: Characterization, validation, and prognostic value. Oncotarget 6:26388 26399, 2015

70. Tap WD, Jones $R L$, Van Tine BA, et al: Olaratumab and doxorubicin versus doxorubicin alone for treatment of soft-tissue sarcoma: An open-label phase $1 \mathrm{~b}$ and randomised phase 2 trial. Lancet 388:488-497, 2016

71. Atkins MB, Larkin J: Immunotherapy combined or sequenced with targeted therapy in the treatment of solid tumors: Current perspectives. J Natl Cancer Inst 108:djv414, 2016
72. Wardelmann $\mathrm{E}$, Haas RL, Bovée JVMG, et al: Evaluation of response after neoadjuvant treatment in soft tissue sarcomas; the European Organization for Research and Treatment of Cancer-Soft Tissue and Bone Sarcoma Group (EORTC-STBSG) recommendations for pathological examination and reporting. Eur J Cancer 53:84-95, 2016

73. Roberge D, Skamene T, Nahal A, et al: Radiological and pathological response following preoperative radiotherapy for soft-tissue sarcoma. Radiother Oncol 97:404-407, 2010

74. Look Hong NJ, Hornicek FJ, Harmon DC, et al: Neoadjuvant chemoradiotherapy for patients with high-risk extremity and truncal sarcomas: A 10-year single institution retrospective study. Eur J Cancer 49:875-883, 2013

75. Miki Y, Ngan S, Clark JCM, et al: The significance of size change of soft tissue sarcoma during preoperative radiotherapy. Eur J Surg Oncol 36: 678-683, 2010

76. Stacchiotti $S$, Collini $P$, Messina $A$, et al: Highgrade soft-tissue sarcomas: Tumor response assessmentpilot study to assess the correlation between radiologic and pathologic response using RECIST and Choi's criteria. Radiology 251:447-456, 2009

77. Stacchiotti $S$, Verderio $P$, Messina $A$, et al: Tumor response assessment by modified Choi criteria in localized high-risk soft tissue sarcoma treated with chemotherapy. Cancer 118:5857-5866, 2012

78. Haas RL: Present and future of radiotherapy before and after surgery for sarcoma patients. Eur J Surg Oncol 40:1595-1597, 2014

79. Messiou C, Bonvalot S, Gronchi A, et al: Evaluation of response after pre-operative radiotherapy in soft tissue sarcomas; the European Organisation for Research and Treatment of Cancer-Soft Tissue and Bone Sarcoma Group (EORTC-STBSG) and Imaging Group recommendations for radiological examination and reporting with an emphasis on magnetic resonance imaging. Eur J Cancer 56:37-44, 2016

80. Winfield JM, Tunariu N, Rata M, et al: Extracranial soft-tissue tumors: Repeatability of apparent diffusion coefficient estimates from diffusion-weighted MR imaging. Radiology 284:88-99, 2017

81. Tran LB, Bol A, Labar D, et al: DW-MRI and (18) F-FLT PET for early assessment of response to radiation therapy associated with hypoxia-driven interventions. Preclinical studies using manipulation of oxygenation and/or dose escalation. Contrast Media Mol Imaging 11:115-121, 2016

82. Messiou C, Orton M, Ang JE, et al: Advanced solid tumors treated with cediranib: Comparison of dynamic contrast-enhanced MR imaging and CT as markers of vascular activity. Radiology 265:426-436, 2012

83. Benz MR, Allen-Auerbach MS, Eilber FC, et al: Combined assessment of metabolic and volumetric changes for assessment of tumor response in patients with soft-tissue sarcomas. J Nucl Med 49: 1579-1584, 2008

\section{Affiliations}

Rick L. Haas, The Netherlands Cancer Institute, Amsterdam; Rick L. Haas, Michiel A.J. van de Sande, and Hans Gelderblom, Leiden University Medical Centre, Leiden, the Netherlands; Alessandro Gronchi, Fondazione IRCCS, Istituto Nazionale dei Tumori, Milan, Italy; Elizabeth H. Baldini, Brigham and Women's Hospital and Dana-Farber Cancer Institute, Boston, MA; Christina Messiou, The Royal Marsden Hospital and The Institute of Cancer Research, London, United Kingdom; Eva Wardelmann, University Hospital Münster, Münster, Germany; Axel Le Cesne, Institut Gustave Roussy, Villejuif, France. 


\section{AUTHORS' DISCLOSURES OF POTENTIAL CONFLICTS OF INTEREST}

Perioperative Management of Extremity Soft Tissue Sarcomas

The following represents disclosure information provided by authors of this manuscript. All relationships are considered compensated. Relationships are self-held unless noted. I = Immediate Family Member, Inst = My Institution. Relationships may not relate to the subject matter of this manuscript. For more information about ASCO's conflict of interest policy, please refer to www.asco.org/rwc or ascopubs.org/jco/site/ifc.

Rick L. Haas

Consulting or Advisory Role: Nanobiotix

Research Funding: GlaxoSmithKline (Inst), Novartis (Inst)

Travel, Accommodations, Expenses: Nanobiotix

\section{Alessandro Gronchi}

Honoraria: Novartis, Pfizer

Consulting or Advisory Role: Novartis, Bayer, Amgen, Eli Lilly, Pfizer Travel, Accommodations, Expenses: PharmaMar

Michiel A.J. van de Sande

Consulting or Advisory Role: Daiichi Sankyo (Inst)

Research Funding: Daiichi Sankyo(Inst), Implantcast (Inst)

Elizabeth H. Baldini

No relationship to disclose

\section{Hans Gelderblom}

Patents, Royalties, Other Intellectual Property: Amgen (Inst), Boehringer-Ingelheim (Inst), Pfizer (Inst), Novartis (Inst), PharmaMar (Inst), Daiichi (Inst), Five Prime (Inst)

Other Relationship: Daiichi Sankyo

\section{Christina Messiou}

No relationship to disclose

Eva Wardelmann

Honoraria: Novartis, Bayer, PharmaMar, Eli Lilly, Nanobiotix Consulting or Advisory Role: Novartis

Research Funding: Novartis

Travel, Accommodations, Expenses: Novartis

Axel Le Cesne

Honoraria: Novartis, PharmaMar, Eli Lilly, Amgen, Pfizer 